\begin{tabular}{c} 
Volume and Issues Obtainable at Center for Sustainability Research and Consultancy \\
Responsible Education, Learning and Teaching in Emerging Economies \\
ISSN: 2708-4310 \& (E): 2708-4183 \\
Volume 3: No.1, June 2021 \\
CSRᄃ \\
Journal homepage: $\underline{\text { www.publishing.globalcsrc.org/relate }}$ \\
\hline
\end{tabular}

\title{
Maintaining Service Quality in Remote Teaching Environment: Case of Lebanese International University
}

*Malak Aoun, Assistant Professor, Management and International Management Department, School of Business, Lebanese International University, Beirut, Lebanon

Nour El Amine, PhD Candidate, Department of Economics and Management, Universitat Rovira i Virgili, Tarragona, Spain

*Corresponding author's email: malak.aoun@liu.edu.lb

\begin{tabular}{l} 
ARTICLE DETAILS \\
\hline History \\
Revised format: May 2021 \\
Available Online: Jun 2021
\end{tabular}

\section{Keywords}

Service quality, Higher Education, Virtual classrooms, Instructor performance, Lebanon

JEL Classification M100, I210, I230 \begin{abstract}
Purpose: The shift from traditional face-to-face classes to virtual classrooms in response to Covid 19 pandemic has affected the higher education sector worldwide, including Lebanon. Among all private universities in Lebanon, the Lebanese International University (LIU) is the largest in terms of enrolment, which enroll $30 \%$ of higher education students in the country. This study evaluates the LIU experience in remote teaching and measures to which extent did the remote instructor performance affected the educational service quality.

Design: By the end of the Fall 2021 semester, a cross-sectional online survey was conducted among students at the School of Business and a total of 450 usable responses pertaining to undergraduate students were considered for data analysis.

Findings: Using SPSS Software, the validity and reliability of the questionnaire has been verified and results showed that remote instructors' performance has a significant and strong positive correlation with all dimensions of service quality; highest for reliability and lowest for tangible. Moreover, regression analysis results showed that $81.5 \%$ of the variance in service quality scores can be predicted from the remote instructors' performance. Implications: Future studies could collect data in a longitudinal manner and include a more representative student sample of the university students.
\end{abstract}

(C) 2021 The authors, under a Creative Commons Attribution NonCommercial 4.0

Recommended citation: Aoun, M., and Amine, N. E. (2021). Maintaining Service Quality in Remote Teaching Environment: Case of Lebanese International University. Responsible Education, Learning and Teaching in Emerging Economies, 3(1), 1-13.

\section{Introduction}

Since January 2020, the outbreak of Covid-19 has rapidly evolved, affecting higher education systems worldwide, including Lebanon (WHO, 2020). On March 15, 2020, the Government of 
Lebanon issued a ministerial decision to close all schools and higher educational institutions in an effort to contain this outbreak (PCM, 2020). As majority of universities, the Lebanese International University (LIU) was rapid to replace face-to-face lectures with remote learning but it has been challenging to sustain the delivery of education while meeting the university's policies and quality requirements. This abrupt transition could have had a negative effect on effectiveness of material covered. As such, one of the ways to do so through measuring the service quality. This presents itself as one of the critical measures of overall higher education institutions' success in mitigating the crises with the least dissatisfaction among students being reported. During times of crisis, students - among others - are put under a huge amount of stress. In fact, Aristovnik et al. (2020) found that during Covid-19 students were mostly worried about their future careers and studies, in addition to the felt anxieties, frustrations, and boredom. These feelings are expected given the sudden changes to students' everyday lives and future prospects.

LIU is the largest private university in Lebanon, with 9 local campuses and more than 30,000 enrolled students, presenting $30 \%$ of total higher education students in the country (CRDP, 2018). As rivalry among higher education institutions increases, universities are considering the students' perspectives of educational service quality in terms of "reliability, assurance, empathy, responsiveness, tangibles, communication, knowledge, expertise, systems, secondary services, social responsibility and self-development" (Yusof \& Ghouri, 2012). On the other hand, instructors are primarily responsible to engage students into the e-learning programs through active learning, motivation and performance related feedback (Yengin et al., 2010). Therefore, the aim of this research is to evaluate the remote instructors' performance at LIU and to study its direct effect on service quality from the students' perspectives.

\section{Service Quality in Higher Education}

As students are selecting the appropriate educational institution carefully, universities are promoting their brands and offers to attract students and retain them through "shifting from a product-led approach towards a more customer-led approach" (Sultan \& Wong, 2010). Actually, higher education in Lebanon had been struggling for a long time to face important challenges of universal nature. Some of these challenges are (1) the relevance of the university programs and research to the socio-economic needs and demands, (2) the rapid expansion of the sector pushed by commercial and sectarian considerations, (3) the lack of organizational and legislative frameworks that govern the higher education sector in terms of quality, services, and continuous education (Alsoufi, 2020). Referring to Czarniecka-Skubina et al. (2019) service quality is described as "a phenomenon considered within the context of customers' expectations and perceptions about the service offered". Foster (2017) demonstrated the Parasuraman, Zeithaml, and Berry (PZB) set of service quality dimensions including "tangibles, reliability, responsiveness, assurance and empathy". In the context of e-services, Ojasalo (2010) suggested eight quality dimensions including "the ease of use, web site design and appearance, personalization, information, responsiveness, communication, security, and reliability”.

Most of the commonly practiced quality approaches in the business world have been amended and implemented in the education sector (Chua, 2004). Researchers have analyzed the service quality in higher education centered on different perspectives such a country, graduate levels, and deployed strategies (Barnes, 2007; Brady et al., 2002; Cheng, 2011; Chong \& Ahmed, 2012; Clemes et al., 2013). Different instruments were developed to measure service quality based on customers' expectations and/or perceptions such as SERVQUAL, SERVPERF, and HEdPERF (Arambewela \& Hall, 2006; Kontic, 2014).

\section{Higher Education in Lebanon and Online Learning}

The connected learning as defined by UNHCR (2014) is "the process of transferring knowledge to learners (students) through the use of information communication technologies (ICTs), that 
enable more flexible learning not bound by the same time or geographical limitations that exist within traditional tertiary programs". Accordingly, El-Ghali and Ghosn (2019) described the following three connected learning methods:

Usually, Lebanese universities use the method of web-facilitated learning which is defined as "courses that are delivered up to $29 \%$ online and uses web-technology to create a more interactive classroom environment that enriches students' learning". But to reach out potential students, they are currently moving towards Blended learning courses that is also known as "hybrid or mixed courses which combine face-to-face learning through the physical presence of the students and the instructor in the classroom and online learning using ICT" (El-Ghali \& Ghosn, 2019). However, e-learning adoption is immature among Lebanese students because of the traditional pedagogies and the weak communication infrastructure, beside other structural, pedagogical, technical, and financial factors (El Turk \& Cherney, 2016; Baroud \& Abouchedid, 2010).

As listed on the Website of the Lebanese Ministry of Education and Higher Education, there is only one Public University (The Lebanese University), 36 Private Universities, 9 University Institutes and Colleges, and 3 University Institutes for Religious Studies. The latest official statistical bulletin for higher education in Lebanon was published by "the Center for Educational Research and Development" (CRDP, 2018). The statistics show that the Lebanese University had the highest students' enrollment (60\%) for the academic year 2017- 2018, followed by the Lebanese International University (LIU), which enrolled $30 \%$ of higher education students. The Lebanese International University is the fastest growing university in Lebanon and it is the largest in terms of enrolment among all private universities in Lebanon.

Although most of the Lebanese universities have Learning Management Systems and use different platforms to convey few online materials to the students, but majority of these universities were not well-prepared for the unexpected and complete movement to the remote teaching modality in response to Covid-19 Pandemic. Therefore, many universities have taken serious actions to mitigate the economic crisis such as reduction in staff, budget cuts, freeze on wages, and control on facilities (El-Ghali \& Nauffal, 2020).

Moreover, Ramadan (2020) listed different technological limitations that obstruct online learning in Lebanon. Basically, there are inadequate internet infrastructures and telecomm nations in the rural areas. In addition, teachers are working extended hours to teach online as they bear all the internet costs to reach students without any compensation. Another challenge is the lack of trained professionals who are unable to support the implementation of remote teaching, where only few teachers are familiar with the online teaching methods.

According to the Economist Intelligence Unit, Lebanon ranked $60^{\text {th }}$ on the world ranking of internet quality among 100 countries based on four major aspects including "availability, affordability, relevance, and readiness" (EIU, 2020). Wazzan (2020) states that the Ministry of Education in Lebanon faces serious decisions regarding the means to regulate the performance of education institutions in the private sector especially that the banking crisis have started embracing these institutions in Lebanon months before the Covid-19 pandemic.

Zgheib, et al. (2020) analyzed the readiness of students in a Lebanese higher education institution to learn online, and found that students are affected by different factors such as access to technology infrastructure, technology skills, social interaction, online communication, motivation, and persistence. Moreover, El-Ghali and Nauffal (2020) state that quality is crucial to higher education sector, whether provided virtual or face-to-face. Universities can build on the 
feedback of students to advance online performance and can rely on technology to reach more learners and increase access to education. However, not all students can access particular technologies and some of them have special needs that are not easily addressed remotely.

As majority of Universities in Lebanon, the Lebanese International University (LIU) has quickly shifted from face-to-face to online classes and by this date, three full online semesters were completed (Spring 2020, Summer 2020, and Fall 2021). At a quick glance, LIU was founded in 2001 and established the first campus in Western Bekaa valley (Al-Khyara) and the second campus in Beirut, which is currently known as BIU. The University comprises five schools including the School of Arts and Science, School of Engineering, School of Business, School of Education, and School of Pharmacy. Later on, LIU expanded and established other campuses in Tripoli, Saida, Mount Lebanon, Nabatieh, Halba-Akkar, Tyre and Rayak. Internationally, LIU went to Yemen and founded four campuses (Aden, Taiz and Sanaa); in addition to one campus in Senegal, and one campus in Mauritania.

The mission of LIU is "to provide accessible and affordable higher education in excellence and quality of first order". This is complemented with a clear vision that leads LIU "to be recognized as Lebanon's leading integrative transnational educator that promotes success to its students through teaching and learning excellence, focused research, and enterprise for career development". In a very short period, LIU experimented different platforms for implementing the online teaching modality and has adopted the Google Classroom as the main platform to interact with students in terms of delivering online sessions, uploading materials, and conducting online assessments. This platform was shown to be user friendly among the different platforms experimented with.

\section{Remote-Instructor Performance}

As an impact of Covid-19 pandemic, the majority of universities worldwide have shifted their classical teaching modes to remote teaching mode. To manage the crisis, universities have adopted different innovative techniques and platforms such as Microsoft Teams, Zoom, Google Classroom, and Webex to take the online classes. The purpose was to not only complete the course, but also to stay in an ongoing touch with the students, escalate the faith and confidence of the students in their school during such ambiguous period (Kaur et al., 2020).

It was essential for instructors to adapt quickly for the sustainability of learning but limited resources and weak infrastructure that restricted its full deployment confronted such reactive strategies. The fluency and expertise with teaching practices in a remote setting vary greatly from one instructor to another (NEE, 2020). In addition to changing the methods of teaching and learning, technology has elevated the role of instructors from delivering knowledge towards working as coaches, co-creators of knowledge, mentors and evaluators (Schleicher, 2020).)

In addition, the performance appraisal process has changed as well. Appraising remote employees has become more difficult because there is lack of regular in-person interaction for supervisors to evaluate. Therefore, routine quantitative metrics might not suitable when evaluating remote employees' performance (McKenna, 2020). However, quality-based metrics are considered key indicators when appraising remote employees such as customer satisfaction and internal feedback processes.

\section{Previous Studies in the Education Sector}


Blended learning has been comprehensively discussed in previous literature (Kaur et al., 2020; Jiménez et al., 2019) in terms of methods, approaches, initiatives, and challenges. However, it is noticeable that this topic has attracted lot of researchers during the Covid-19 pandemic because of its great impact in implementing the current educational strategies. Kaur et al. (2020) conducted an online cross sectional survey among 983 medical students in India. The results revealed that online classes are equally effective in five parameters which are "contributing to communication, building skills and knowledge, offering better understanding through recorded classes, grooming of professional career, and in assignment submission". Although students were not considerably satisfied with this teaching method, but it was the need of that moment. The study concluded that e-education can complement the process of existing education, but it is difficult to be used as a substitute for the traditional educational system.

From the quality perspective, Hoon and Satiman (2016) investigated the service quality level from the perception of 93 teachers in private schools in Selangor, Malaysia using the SERVQUAL instrument. The results indicated that teachers had significant high perception for all the service quality dimensions and particularly for empathy and assurance.

Furthermore, Mohamed and El-Zeftawy (2016) assessed the perception of 314 health nursing undergraduate students regarding blended learning at Tanta University in Egypt. The results showed that $40 \%$ of students have a positive perception about the target blended course and consider that its service and instruction was conveyed as promised. However, $60.5 \%$ of students were not satisfied from the web site browsing process and the low level of instructor interaction. Based on the above discussions, this study emphasizes on the perspective of students in evaluating the instructors' performance since they are directly affected by this performance and they present a reliable source of information in the remote learning approach. To achieve the research objectives, the subsequent hypotheses are proposed:

$\mathbf{H}_{\mathbf{1}}$ : there is a significant and positive relationship between remote instructors' performance and service quality.

$\mathbf{H}_{\mathbf{a}}$ : there is a significant and positive relationship between remote instructors' performance and tangibles

$\mathbf{H}_{\mathbf{b}}$ : there is a significant and positive relationship between remote instructors' performance and reliability.

$\mathbf{H}_{\mathbf{c}}$ : there is a significant and positive relationship between remote instructors' performance and responsiveness.

$\mathbf{H}_{\mathbf{d}}$ : there is a significant and positive relationship between remote instructors' performance and assurance.

$\mathbf{H}_{\mathbf{e}}$ : there is a significant and positive relationship between remote instructors' performance and empathy.

$\mathbf{H}_{2}$ : Remote instructors' performance has a significant and positive effect on service quality

\section{Research Methodology}

The aim of this study is to determine the effect of remote instructors' performance on the service quality from the perspective of undergraduate students in the School of Business (SoB) at the Lebanese International University. For this purpose, a quantitative methodology was applied based on a deductive approach through conducting a cross-sectional, online survey among the students by the end of the Fall 2020-2021 semester (January 2021).

\section{Population and Sample Size}

Based on the latest statistical report by the School of Business at LIU, the total number of students in the School of business for the Fall 2020-2021 semester is 11833 (SoB, 2021), which represents the research population. Based on Krejcie and Morgan (1970), an appropriate sample 
size for such population is 370 at a $95 \%$ confidence interval and $5 \%$ margin of error. However, the rule of thumb by Roscoe (1975) states that "a sample size larger than 30 and less than 500 is appropriate for most researches". Moreover, the simple random sampling technique was applied to give students an equal chance of being selected in this online survey.

\section{Survey Instrument}

The primary data for this research was collected through an online questionnaire instrument. The design of the online questionnaire was divided into three main sections, A, B, and C. Section A and B measure the research variables based on 5-point Likert scale ranging from (1) Strongly disagree to (5) strongly agree. Section A measures service quality (dependent variable) through its five dimensions: responsiveness, tangibles, empathy, service reliability and assurance. All 17 items were adapted from SERVQUAL, which is a standard, valid and reliable tool developed by Parasuraman, Zeithamel, and Berry (Foster, 2017). Moreover, this tool has been widely applied in a variety of contexts, including the education sector and its was approved as a valid and reliable instrument (Datta \&Vardhan, 2018; Hoon \& Satiman, 2016).

Section B measures the remote instructors' performance (independent variable) through 12 items which are adapted from valid and reliable instruments. Such instruments evaluated different dimensions of teachers' performance such as effectiveness, adaptability, flexibility, communication, interaction, skills, knowledge, and competencies (Kocak, 2006; Paul, 2006). Section $\mathrm{C}$ identifies the demographic characteristics of the respondents in terms of gender, age, campus, major, program of study, academic year, online semester, and working status. After securing the ethical approval from the Institutional Review Board (IRB) at the University to conduct this research, the online questionnaire was prepared using Google Forms and the link was sent to all SoBu students through their LIU emails. A consent letter was also attached to inform students that their participation is voluntary and that their identity will remain anonymous.

\section{Data Analysis and Results}

After one week of surveying, a total of 620 responses were collected. First, responses were filtered to exclude any missing or irrelevant data. As a preliminary stage, 77 responses were excluded due to missing data, resulting in 543 usable responses. Since this research focuses on the SoBu undergraduate students, responses were filtered again based on program of study in which responses of 93 Graduate students were excluded. Therefore, the valid number of this online survey responses is 450. Then, data was analyzed using SPSS software to obtain descriptive statistics and to measure the proposed hypotheses.

\section{Demographic Characteristics}

Majority of the respondents are females (51.1\%), aged between 21 and 23 years (48.4\%). Most of respondents are enrolled in Beirut Campus (40.9\%) and have Business Management major $(25.8 \%)$. Results also show that majority of respondents are senior students in their third academic year $(60.2 \%)$ and that this is their $3^{\text {rd }}$ semester online $(72.2 \%)$. It is also noticeable that $56.9 \%$ of students are working while studying.

\section{Validity and Reliability}

Validity of the survey instrument is tested via exploratory factor analysis (EFA). Basically, the KMO measure of sampling adequacy should be greater than 0.5 and the Bartlett's test of sphericity should be significant with p-value $<0.05$ (Hair et al., 2010). As shown in Table 1, all results indicate validity of instrument.

Table 1: Exploratory factor analysis Results 


\begin{tabular}{|l|l|c|c|c|}
\hline & $\begin{array}{l}\text { Kaiser-Meyer-Olkin Measure } \\
\text { of Sampling Adequacy }\end{array}$ & 0.962 & 0.958 & 0.976 \\
\hline \multirow{2}{*}{$\begin{array}{c}\text { Bartlett's Test } \\
\text { of Sphericity }\end{array}$} & Approx. Chi-Square & 5161.771 & 4277.940 & 10586.249 \\
\cline { 2 - 5 } & $\mathrm{df}$ & 136 & 66 & 406 \\
\cline { 2 - 5 } & Sig. & 0.000 & 0.000 & 0.000 \\
\hline
\end{tabular}

Moreover, the items of this instrument show high internal consistency for the independent variable (instructors' performance), dependent variable (service quality), and both variables as well. The Cronbach's Alpha values are greater than 0.7 for all items as shown in Table 2. So according to Hair et al., (2010), this instrument is reliable.

Table 2: Reliability Test

\begin{tabular}{|c|c|c|}
\hline \multicolumn{3}{|c|}{ Reliability Statistics } \\
\hline & Cronbach's Alpha & Number of Items \\
\hline Service Quality & 0.949 & 17 \\
\hline Instructors' Performance & 0.952 & 12 \\
\hline All variables & 0.972 & 29 \\
\hline
\end{tabular}

\section{Descriptive Statistics}

Majority of students showed a favorable outlook towards the instructors' performance and service quality. The averages of each service quality dimension are calculated and results in table 3 show that standard deviation values are high and close to one, ranging between $(0.76-0.924)$, meaning that data are well spread over a large range of values. In addition, the average mean values range between (3.47 and 4.12), which indicates a score range "agree" in reference to the 5Likert scale (1.00 - 1.80) strongly disagree, (1.81 - 2.60) disagree, (2.61 - 3.40) neutral or moderately agree, (3.41 - 4.20) agree, (4.21 - 5.00) strongly agree (Torres \& Manuzon, 2020). Among the service quality dimensions, assurance has the highest average mean (4.12), followed by tangibles (3.93), reliability (3.80), responsiveness (3.66), and empathy (3.47).

Table 3: Descriptive Statistics

\begin{tabular}{|c|c|c|c|c|c|}
\hline \multicolumn{7}{|c|}{ Descriptive Statistics } \\
\hline $\begin{array}{c}\text { Instructors' } \\
\text { Performance }\end{array}$ & 450 & 1 & 5 & 3.80 & 0.784 \\
\hline Tangible & 450 & 1 & 5 & 3.93 & 0.795 \\
\hline Reliability & 450 & 1 & 5 & 3.80 & 0.853 \\
\hline Responsiveness & 450 & 1 & 5 & 3.66 & 0.913 \\
\hline Assurance & 450 & 1 & 5 & 4.12 & 0.818 \\
\hline Empathy & 450 & 1 & 5 & 3.47 & 0.924 \\
\hline Service Quality & 450 & 1 & 5 & 3.80 & 0.760 \\
\hline
\end{tabular}

For more details, Table 4 illustrates the descriptive statistics of each item in the survey instrument. As for the items of tangibles, results show that students have the highest positive perception about the detailed course schedules and syllabi (4.11). For the reliability dimension, students show the highest positive perception about the instructors who provide educational services at the time they promise to do so (4.04). Moreover, students perceive instructors as responsive and they perform services right the first time (3.72). As for assurance, students agree that instructors are consistently courteous to them (4.19). As for the last service quality dimension, students perceive instructors as empathetic and they understand their needs (3.64). It should be noted that the lowest mean among all the items of the previous dimensions is (3.22) and it shows that students are neutral regarding the convenience of the assessment hours. On the other hand, students evaluated the instructors' performance and means ranged between (3.44 and 
4.20) indicating a score of agreement. Majority of students agree that instructors follow the course schedule and syllabus however; a lower student perception is addressed for instructors evaluating their progress regularly.

Table 4: Detailed Descriptive Statistics

\begin{tabular}{|c|c|c|c|}
\hline & Descriptive Statistics & & \\
\hline & & Mean & $\begin{array}{c}\text { Std. } \\
\text { Deviation }\end{array}$ \\
\hline Tan1 & Power points are well prepared. & 3.92 & 0.976 \\
\hline Tan2 & Voice-overs are clear. & 3.57 & 1.113 \\
\hline Tan3 & Course schedules and syllabi are detailed. & 4.11 & 0.975 \\
\hline Tan4 & Google Classroom platform is always updated by the instructor and it is user friendly. & 4.11 & 0.945 \\
\hline Rel1 & When I have a problem, instructors show a sincere interest in solving it. & 3.75 & 1.120 \\
\hline Rel2 & The instructors provide educational services at the time they promise to do so. & 4.04 & 0.911 \\
\hline Rel3 & Instructors keep accurate records about my progress. & 3.56 & 1.030 \\
\hline Rel4 & Instructors provide their services within the time one might reasonably expect. & 3.84 & 0.957 \\
\hline Resp1 & Instructors are never too busy to respond to a request for assistance. & 3.60 & 1.133 \\
\hline Resp2 & Instructors deal with me promptly when requesting assistance. & 3.66 & 1.023 \\
\hline Resp3 & Instructors perform services right the first time. & 3.72 & 0.945 \\
\hline Ass 1 & Instructors have the knowledge to answer my questions relating to course provision. & 4.13 & 0.878 \\
\hline Ass2 & Instructors are consistently courteous (polite) to me. & 4.19 & 0.951 \\
\hline Ass3 & I have confidence in my instructors. & 4.05 & 0.980 \\
\hline Emp1 & Assessment hours are convenient for me. & 3.22 & 1.236 \\
\hline Emp2 & Instructors understand the needs of their students. & 3.64 & 1.073 \\
\hline Emp3 & Instructors are willing to give students individual attention. & 3.53 & 1.072 \\
\hline IV1 & Instructors encourage students to analyze critically. & 3.66 & 0.980 \\
\hline IV2 & Instructors engage with students in problem solving activities. & 3.78 & 1.002 \\
\hline IV3 & Instructors use motivating strategies to engage students. & 3.70 & 1.041 \\
\hline IV4 & Instructors follow the course schedule and syllabus. & 4.20 & 0.846 \\
\hline IV5 & Instructors establish rapport with their students. & 3.58 & 0.939 \\
\hline IV6 & Instructors evaluate students' progress regularly. & 3.44 & 1.037 \\
\hline IV7 & Instructors use technology and media tools professionally to communicate with students. & 3.79 & 1.003 \\
\hline IV8 & Instructors are competent and possess the required skills and knowledge. & 3.87 & 0.920 \\
\hline IV9 & Instructors are committed to time and deliver full online sessions. & 3.98 & 0.977 \\
\hline IV10 & Instructors are assertive in controlling online sessions. & 3.80 & 0.937 \\
\hline IV11 & Instructors allow students to access and use information. & 3.89 & 0.933 \\
\hline IV12 & Instructors treat students on equal basis. & 3.94 & 1.003 \\
\hline
\end{tabular}

\section{Hypotheses Testing}

To test the research hypotheses, Correlation test was conducted to measure the linear relationship between the research variables based on Pearson correlation coefficient (r). Then, Regression and ANOVA test was analyzed to determine to which extent the instructors' performance affected service quality during remote teaching.

Table 5 shows the Correlation test results. According to Hair et al., (2010), strong correlation between two variables exists of $\pm 0.50<\mathrm{r}< \pm 1$. Therefore, instructors' performance has a significant and strong positive correlation with all dimensions of service quality; highest for reliability (0.849) and lowest for tangible (0.766). 
Table 5: Correlations' Test Results

\begin{tabular}{|c|c|c|c|c|c|}
\hline & & Performance & Tangible & Reliability & Responsiveness \\
\hline \multirow[t]{3}{*}{ Performance } & Pearson Correlation & 1 & $0.766^{* *}$ & $0.849^{* * *}$ & $0.793^{*}$ \\
\hline & Sig. (2-tailed) & & 0.000 & 0.000 & 0.000 \\
\hline & $\mathrm{N}$ & 450 & 450 & 450 & 450 \\
\hline \multirow[t]{3}{*}{ Tangible } & Pearson Correlation & $0.766^{* *}$ & 1 & $0.752^{* * *}$ & $0.693^{* *}$ \\
\hline & Sig. (2-tailed) & 0.000 & & 0.000 & 0.000 \\
\hline & $\mathrm{N}$ & 450 & 450 & 450 & 450 \\
\hline \multirow[t]{3}{*}{ Reliability } & Pearson Correlation & $0.849^{* *}$ & $0.752^{* *}$ & 1 & $0.839^{*}$ \\
\hline & Sig. (2-tailed) & 0.000 & 0.000 & & 0.000 \\
\hline & $\mathrm{N}$ & 450 & 450 & 450 & 450 \\
\hline \multirow[t]{3}{*}{ Responsiveness } & Pearson Correlation & $0.793^{* *}$ & $0.693^{* *}$ & $0.839^{* * *}$ & 1 \\
\hline & Sig. (2-tailed) & 0.000 & 0.000 & 0.000 & \\
\hline & $\mathrm{N}$ & 450 & 450 & 450 & 450 \\
\hline \multirow[t]{3}{*}{ Assurance } & Pearson Correlation & $0.814^{* *}$ & $0.709^{* *}$ & $0.775^{* *}$ & $0.734^{*}$ \\
\hline & Sig. (2-tailed) & 0.000 & 0.000 & 0.000 & 0.000 \\
\hline & $\mathrm{N}$ & 450 & 450 & 450 & 450 \\
\hline \multirow[t]{3}{*}{ Empathy } & Pearson Correlation & $0.777^{* *}$ & $0.669^{* *}$ & $0.737^{* * *}$ & $0.718^{* *}$ \\
\hline & Sig. (2-tailed) & 0.000 & 0.000 & 0.000 & 0.000 \\
\hline & $\mathrm{N}$ & 450 & 450 & 450 & 450 \\
\hline \multirow[t]{3}{*}{ Service Quality } & Pearson Correlation & $0.903^{* *}$ & $0.870^{* *}$ & $0.933^{* *}$ & $0.898^{*}$ \\
\hline & Sig. (2-tailed) & 0.000 & 0.000 & 0.000 & 0.000 \\
\hline & $\mathrm{N}$ & 450 & 450 & 450 & 450 \\
\hline
\end{tabular}

**. Correlation is significant at the 0.01 level (2-tailed).

The second step is to conduct Regression Analysis. As specified in Table 6, R- Square value indicates that $81.5 \%$ of the variance in service quality scores can be predicted from the instructors' performance.

Table 6: Regression Analysis (Model Summary)

\begin{tabular}{|l|c|r|r|r|}
\hline Model & $\mathrm{R}$ & R Square & \multicolumn{1}{c|}{$\begin{array}{c}\text { Adjusted R } \\
\text { Square }\end{array}$} & $\begin{array}{c}\text { Std. Error of the } \\
\text { Estimate }\end{array}$ \\
\hline 1 & $0.903^{\mathrm{a}}$ & 0.815 & 0.814 & 0.327 \\
\hline
\end{tabular}

a. Predictors: (Constant), Performance

The main objective is to answer the following question; does instructors' performance reliably predict the service quality? Tables 7 and 8 show that the p-values associated with the F-values and t-values are less than 0.05. Thus, instructors' performance has a positive and significant effect on service quality and consequently, all the proposed research hypotheses are accepted.

\section{Table 7: ANOVA Results}

\begin{tabular}{|l|l|r|r|r|r|r|}
\hline \multicolumn{2}{|l|}{ Model } & Sum of Squares & Df & Mean Square & \multicolumn{1}{c|}{ F } & Sig. \\
\hline \multirow{3}{*}{1} & Regression & 211.137 & 1 & 211.137 & 1969.425 & $0.000^{\mathrm{a}}$ \\
\cline { 2 - 7 } & Residual & 48.029 & 448 & 0.107 & & \\
\cline { 2 - 7 } & Total & 259.166 & 449 & & & \\
\hline
\end{tabular}

a. Predictors: (Constant), Performance

b. Dependent Variable: Service Quality 
Table 8: Coefficients Results

\begin{tabular}{|c|c|c|c|c|c|c|c|c|}
\hline \multirow{2}{*}{\multicolumn{2}{|c|}{ Model }} & \multicolumn{2}{|c|}{$\begin{array}{l}\text { Unstandardized } \\
\text { Coefficients }\end{array}$} & \multirow{2}{*}{$\begin{array}{c}\text { Standardized } \\
\text { Coefficients } \\
\text { Beta } \\
\end{array}$} & \multirow[b]{2}{*}{$\mathrm{t}$} & \multirow[b]{2}{*}{ Sig. } & \multicolumn{2}{|c|}{$\begin{array}{c}95.0 \% \\
\text { Confidence } \\
\text { Interval for B }\end{array}$} \\
\hline & & B & $\begin{array}{l}\text { Std. } \\
\text { Error }\end{array}$ & & & & $\begin{array}{l}\text { Lower } \\
\text { Bound }\end{array}$ & $\begin{array}{l}\text { Upper } \\
\text { Bound }\end{array}$ \\
\hline \multirow[t]{2}{*}{1} & (Constant) & 0.477 & 0.077 & & 6.236 & 0.000 & 0.327 & 0.627 \\
\hline & Performance & 0.874 & 0.020 & 0.903 & 44.378 & 0.000 & 0.836 & 0.913 \\
\hline
\end{tabular}

a. Dependent Variable: Service Quality

\section{Discussion and Conclusion}

The results indicate that students were generally satisfied with the remote performance of instructors, among other variables, thus positively reflecting on the overall satisfaction with the service quality. Undoubtedly, the impact of Covid-19 on students' wellbeing has been that of a negative one. Aristovnik et al. (2020) found that during Covid-19 students were mainly concerned about their future careers and studies, in addition to the felt anxieties, frustrations, and boredom. As such, for students to realize that despite all the surrounding uncertainties, the quality of the educational service they are getting did not change - albeit the mode of delivery has - may help attenuate their anxieties. Moreover, the key role played by teaching and support staff has largely contributed to maintaining students' satisfaction with the overall service quality. Our results show that instructors' performance has a significant and strong positive correlation with all dimensions of service quality. This reflects on the level of comfort students feel. In line with Aristovnik et al. (2020)'s study which established that "on the global level, students were quite satisfied with the organization of all three segments of the pedagogical process: Lectures, tutorials/seminars, and mentorships" (p.18), our sample student reports similar sentiments.

A further explanation to why service quality was perceived in such a positive manner, is the fact that LIU adopted synchronous learning rather than asynchronous. This has further augmented the student samples' satisfaction with the overall service. In particular, seeing instructors on weekly basis, for one to two times, and having the material explained in a live session where discussion and questions are heavily encouraged, facilitated students understanding, and provided them with a slight sense of normality. Moreover, such live interaction contributed to decreasing any confusion and helped foster a sense of community engagement (Watts, 2016). Furthermore, instructors reflecting an image of preparedness from the onset of term and throughout it may have allowed students become more mentally organized. Undoubtedly, living in a country where Covid is not the only uncertainty students experience. Lebanon has been witnessing a series of unfortunate events, from the political and economic meltdown to the humanitarian crisis and most recently the August 4 explosion. Such circumstances have amplified the feelings of stress among the students on top of those triggered by Covid. That is why the perceived instructor empathy was also valuable in enhancing the overall satisfaction of the quality service despite it scoring one of the lowest means. To that extent, perhaps instructors should enhance their empathy and provide increased support where needed for students which could augment the perceived service quality.

With regards to the reliability and tangibility dimensions, the fact that the material for the course were prepared and shared via the adopted platform well in advance has been positively received by students. Making the material available, has provided students with a sense of controllability. They are capable of managing the various responsibilities that lie on them given that the majority of these students are working ones. The shift to online classes has also made it easier on them to 
pursue their studies at a more comfortable pace than when it was physical particularly that the tangible aspects of the course are made available in various formats for the online classes.

In conclusion, although the transition from physical to online had been an abrupt one, it seems that overall, students are more satisfied with the service quality. Particularly, this is heavily reliant on the instructor's general performance as the former is the focal point between the university and the students despite the fact that instructors could improve themselves on some particular dimensions such as empathy.

The limitations of this study provide various avenues for future research. A more representative student sample of the university students could have been included. This study was particularly directed at the school of business, however, different faculties and schools could have been included for comparative reasons. For instance, how does the perceived satisfaction for students within the life sciences department given that their university experience heavily relies on their physical presence for lab work vary from those in other faculties. Data could be collected in a longitudinal manner. A longitudinal study could capture students changing satisfaction as more time elapses. This would be important given the evolution of the changing nature of Covid's restrictions and as the longing for the old way of life becomes more salient. Given that this study only measured the perceived service quality, the overall attitude towards to the university as a result of this perceived service quality could also be measured. Thus, allowing universities to close any gaps in their perceived images.

\section{References}

Alsoufi, A. (2020). Editorial, the National Erasmus-plus Office, Lebanon, January-March, Issue 2. Available at: http://erasmuspluslebanon.org/sites/default/files/documents/NEWSLETTER\%202\%20January_March\%202 020.pdf

Aristovnik, A., Keržič, D., Ravšelj, D., Tomaževič, N., \& Umek, L. (2020). Impacts of the COVID-19 pandemic on life of higher education students: A global perspective. Sustainability, 12(20), 8438.

Baroud, F. (2011). The development of e-learning in a Lebanese higher education context (Doctoral dissertation, Sheffield Hallam University). Available at: http://shura.shu.ac.uk/20607/

Brady, M.K., Cronin, J.J. and Brand, R.R. (2002). Performance-only measurement of service quality: a replication and extension, Journal of Business Research, 55 (1), 17-31.

Calvo-Porral, C., Lévy-Mangin, J.P. and Novo-Corti, I. (2013). Perceived quality in higher education: an empirical study, Marketing Intelligence \& Planning, 31 (6), 601-619.

Cheng, M. (2011). Transforming the learner' versus 'passing the exam': understanding the gap between academic and student definitions of quality, Quality in Higher Education, 17 (1), 3-17.

Chong, Y.S. and Ahmed, P.K. (2012). An empirical investigation of students' motivational impact upon university service quality perception: a self- determination perspective, Quality in Higher Education, 18 (1), 37-41.

Clemes, M.D., Cohen, D.A. and Wang, Y. (2013). Understanding Chinese university students' experiences: an empirical analysis, Asia Pacific Journal of Marketing and Logistics, 25 (3), 391-427.

CRDP (2018). Statistical Bulletin for the Academic Year 2017-2018. The Center for Educational Research and Development, Lebanon. Available at: https://www.crdp.org/statisticsbulletin

Czarniecka-Skubina, E., et al. (2019). Consumer choices and service quality in the university canteens in Warsaw, Poland. International journal of environmental research and public health, 16(19), 3699. 
Datta, K. S., \& Vardhan, J. (2017). A SERVQUAL-based framework for assessing quality of international branch campuses in UAE: A management students' perspective. SAGE Open, 7(1), 2158244016676294.

El Turk, S., \& Cherney, I. D. (2016). Perceived online education barriers of administrators and faculty at a US university in Lebanon. Creighton Journal of Interdisciplinary Leadership, 2(1), 15-31.

El-Ghali, A. \& Nauffal, D. (2020). COVID19: Is Lebanon Ready for Online Higher Education? National Erasmus-plus Office, Lebanon, January-March, Issue 2, pp. 8-9. Available at: http://erasmusplus-

lebanon.org/sites/default/files/documents/NEWSLETTER\%202\%20January_March\%202 020.pdf

El-Ghali, H. \& Ghosn, E. (2019). Towards connected learning in Lebanon. Issam Fares Institute for Public Policy and International Affairs, American University of Beirut, Lebanon. Available at: https://www.aub.edu.lb/ifi/Pages/publications/research_reports/20182019/20190221-towards-connected-learning-in-lebanon.aspx

El-Zeftawy, A. M. A., \& Hassan, L. A. E. W. A. E. A. (2016). Perception of students regarding blended learning implementation of community health nursing course at faculty of nursing, Tanta University, Egypt. Journal of Nursing Education and Practice, 7(3), 8393.

Foster, S. Thomas. (2017). Managing quality: integrating the supply chain, Pearson; 6th edition.

Griffin, B., \& Hesketh, B. (2003). Adaptable behaviours for successful work and career adjustment. Australian Journal of psychology, 55(2), 65-73.

Hoon, T. S., \& Satiman, F. (2016). An Investigation on the Dimensions of Service Quality in Private Schools. Asian Journal of University Education, 12(1), 39-51.

Kaur, N., Dwivedi, D., Arora, J., \& Gandhi, A. (2020). Study of the effectiveness of e-learning to conventional teaching in medical undergraduates amid COVID-19 pandemic. National Journal of Physiology, Pharmacy and Pharmacology, 10(7), 1-5.

Koçak, R. (2006). The Validity and Reliability of the Teachers' Performance Evaluation Scale. Educational Sciences: Theory \& Practice, 6(3).

Kontic, L. (2014, June). Measuring service quality in higher education: the case of Serbia. In Human Capital without Borders: Knowledge and Learning for Quality of Life. Proceedings of the Management, Knowledge and Learning International Conference (pp. 645-654).

Krejcie, R. V., \& Morgan, D. W. (1970). Determining sample size for research activities. Educational and psychological measurement, 30(3), 607-610.

McKenna, P. (2020). Evaluating the Performance of Remote Employees, New Focus HR, Indianapolis, 13 May. Available at: https://newfocushr.com/2020/05/13/evaluating-theperformance-of-remote-employees/ (Accessed on 15 January 2021).

NEE (2020). Adaptability and growth: evaluating effective teaching in remote learning environments, The Network for Educator Effectiveness. Available at: https://neeadvantage.com/evaluating-remote-teaching/. (Accessed on 20 January 2021).

NIET (2020). Instructional Strategies for Virtual Learning: A Companion Tool to the NIET Teaching Standards Rubric What effective teaching looks and sounds like in a virtual setting, NIET, September. Available at: https://www.niet.org/assets/Resources/1d7f05267d/niet-rubric-companion-for-virtualinstruction.pdf

Parasuraman, A. Zeithaml, V. A. and Berry, L. L. (1988). SERVQUAL: a multiple-item scale for measuring consumer perceptions of services quality. Journal of Retailing, 64(1), 12-40.

Paul, S. (2006, November). Comparative Assessment of the Effectiveness of Online Vs Paper Based. In 2006 International Conference on Computational Inteligence for Modelling Control and Automation and International Conference on Intelligent Agents Web 
Technologies and International Commerce, 271-271.

PCM (2020). Decision n1. Presidency of the Council of Ministers, Lebanon, 15 March. Available at: http://www.pcm.gov.lb/arabic/subpg.aspx?pageid=17370

Ramadan, T. (2020). Remote Learning and the Digital Divide in Lebanon, SMEX, 22 October, Lebanon. Available at: https://smex.org/remote-learning-and-the-digital-divide-inlebanon/ (Accessed on 20 January 2021).

Schleicher, A. (2020). The impact of covid-19 on education insights from education at a glance 2020, OECD. Available at: https://www.oecd.org/education/the-impact-of-covid-19-oneducation-insights-education-at-a-glance-2020.pdf. (Accessed on 25 January 2021).

Sultan, P. and Wong, H. (2010). Performance-based service quality model: an empirical study on Japanese universities. Quality Assurance in Education, 18(2), 126-43.

Torres, M. V., \& Manuzon, E. P. (2020). Facilities and Services: An Assessment of Academic Institutions in Nueva Ecija. International Journal of Advanced Engineering Research and Science, 7(6).

Torres, N. H. J., San Martín, S., Torrico, P. R., \& Sánchez-Beato, E. J. (2019). The most waited engagement in higher education: Teachers and students' committed with elearning. Journal of Management and Business Education, 2(3), 231-249.

UNHCR. (2014). Roundtable report on connected higher learning programs for refugees. UNHCR Education Unit \& Innovation. Available at: https://www.scribd.com/document/247750770/UNHCR-Connected-Learning-Report

Watts, L. (2016). Synchronous and asynchronous communication in distance learning: A review of the literature. Quarterly Review of Distance Education, 17(1), 23-32.

Wazzan, M. (2020). Learning Remotely as the Only Resort: How is Lebanon Doing? Al-Fanar Media, 2 April, Lebanon. Available at: https://www.al-fanarmedia.org/2020/04/learningremotely-as-the-only-resort-how-is-lebanon-doing/ (Accessed on 25 January 2021).

Yengin, İ., Karahoca, D., Karahoca, A., \& Yücel, A. (2010). Roles of teachers in e-learning: How to engage students \& how to get free e-learning and the future. Procedia-Social and Behavioral Sciences, 2(2), 5775-5787.

Yusof, A., et al. (2012). Educational service quality at public higher educational institutions: A proposed framework and importance of the sub-dimensions. International Journal of Economics Business and Management Studies, 1(2), 36-49.

Zgheib, G., et al. (2020). Factors Influencing Students' Online Learning Readiness in a Middle Eastern Higher Education Institution: Implications for Online Course Design. International Jl. on E-Learning, 19(3), 287-308. 